6 McKay RG, Safian RD, Lock JE, et al. Assessment of left ventricular and aortic valve function after aortic balloon valvuloplasty in adult patients with critical aortic stenosis. Circulation 1987;75:192-203.

7 Cribier A, Savin T, Berland J, et al. Percutaneous transluminal balloon valvuloplasty of adult aortic stenosis: report of 92 cases. $\mathcal{J} \mathrm{Am}$ Coll Cardiol 1987;9:381-8.

8 Drobinski G, Lechat P, Metzger JP, Lepailleur C, Vacheron A, Grosgogeat Y Results of percutaneous catheter valvuloplasty for calcified aortic stenosis in the elderly. Eur Heart $f$ 1987:8:322-8.

9 Isner JM, Salem DN, Desnoyers MR, et al. Treatment of calcific aortic stenosis by balloon valvuloplasty. $A m \mathcal{F}$ Cardiol 1987;59:313-7.

10 Schneider JF, Wilson M, Gallant TE. Percutaneous balloon aortic valvuloplasty for aortic stenosis in elderly patients at high risk for surgery. Ann Intern Med 1987;106:696-9.

11 Criteria Committee, New York Heart Association. Diseases of the heart and blood vessels: nomenclature and criteria for diagnosis. 6th ed. Boston: Little, Brown, 1964.

12 Judkins MP. Selective coronary arteriography. Part I: a percutaneous transfemoral technic. Radiology 1967;89:815-24.

13 Hatle L, Angelsen BA, Tromsdal A. Noninvasive assessment of aortic stenosi by Doppler ultrasound. Br Heart $\mathcal{F}$ 1980;43:284-92.

14 Currie PJ, Seward JB, Reeder GS, et al . Continuous-wave Doppler echocardiographic assessment of severity of calcific aortic stenosis: a simultaneous Doppler-catheter correlative study in 100 adult patients. Circulation 1985;71:1162-9.

15 Skjaerpe T, Hegrenaes L, Hatle L. Noninvasive estimation of valve area in patients with aortic stenosis by Doppler ultrasound and two-dimensional patients with aortic stenosis by Doppler u-8.

16 Zoghbi WA, Farmer KL, Soto JG, Nelson JG, Quinones MA. Accurate noninvasive quantification of stenotic aortic valve area by Doppler echocardiography. Circulation 1986;73:452.9.

17 Otto CM, Pearlman AS, Janko CL, Kraft CD, Fujioka MC. Simplification of the Doppler continuity equation for calculating stenotic aortic valve area [Abstract]. $\mathcal{F}$ Am Coll Cardiol 1987;9:236A.

18 Come PC, Riley MF, McKay RG, Safian R. Echocardiographic assessment of aortic valve area in elderly patients with aortic stenosis and of changes in valve area after percutaneous balloon valvuloplasty. $\mathcal{F} \mathrm{Am}$ Coll Cardio 1987;10:115-24.

19 Cutler SJ, Ederer F. Maximum utilization of the life table method in analyzing survival. $\mathcal{F}$ Chronic Dis 1958;8:699-712.

20 Roberts WC, Perloff JK, Constantino T. Severe valvutar aortic stenosis in patients over 65 years of age: a clinicopathologic study. Am $\mathcal{J}$ Cardiol 1971;27:497-506.

21 Pomerance A. Pathogenesis of aortic stenosis and its relation to age. Br Heart 1972;34:569-74.
22 Selzer A. Changing aspects of the natural history of valvular aortic stenosis. $N$ Engl f Med 1987;317:91-8.

23 Safian RD, Mandell VS, Thurer RE, et al. Postmortem and intraoperative balloon valvuloplasty of calcific aortic stenosis in elderly patients: mechanisms of successful dilation. $f$ Am Coll Cardiol 1987;9:655-60.

24 Robicsék F, Harbold NB Jr. Limited value of balloon dilatation in calcified aortic stenosis in adults: direct observations during open heart surgery. $A m \mathcal{F}$ Cardiol 1987;60:857-64.

25 Commeau P, Grollier G, Lamy E, et al. Percutaneous balloon dilatation of calcific aortic valve stenosis: anatomical and haemodynamic evaluation. Br Hearl f 1988;59:227-38.

26 Berland J, Cribier A, Savin T, Letac B. Does the severity of aortic stenosis influence results of balloon valvuloplasty [Abstract]. Circulation 1987;76 (suppl IV):76.

27 Wagner S, Selzer A. Patterns of progression of aortic stenosis: a longitudinal hemodynamic study. Circulation 1982;65:709-12.

28 Chang S, Clements S, Chang J. Aortic stenosis: echocardiographic cusp separation and surgical description of aortic valve in 22 patients. $A m \mathcal{F}$ Cardiol 1977;39:499-504.

29 Goldman L, Hashimoto B, Cook EF, Loscalzo A. Comparative reproducibility and validity of systems for assessing cardiovascular functional class: advantages of anew specific activity scale. Circulation 1981;64:1227-34.

30 Nylander E, Ekman I, Marklund T, Sinnerstad B, Karlsson E, Wranne B Severe aortic stenosis in elderly patients. Br Heart $\mathcal{F}$ 1986;55:480-7.

31 Lipkin DP, Scriven AJ, Crake T, Poole-Wilson PA. Six minute walking test for assessing exercise capacity in patients with chronic heart failure. Br Med f 1986;292:653-5.

32 Ross J Jr, Braunwald E. Aortic stenosis. Circulation 1968;38 (suppl 5):V. 61-7. 33 Chizner MA, Pearle DL, de Leon AC Jr. The natural history of aortic stenosis in adults. Am Heart $\mathcal{O}$ 1980;99:419-24.

34 O'Keefe JH Jr, Vlietstra RE, Holmes DR Jr, Bailey KR. Natural history of candidates for balloon aortic valvuloplasty. Mayo Clin Proc 1987;62:986-91.

35 Larmi TKI, Kairaluoma MI, Karkola P, Tuononen S, Nuutinen L. Intraoperative hemodynamic evaluation of the Björk-Shiley tilting disc aortic valve. I Thorac Cardiovasc Surg 1977;73:712-5.

36 Chaitman BR, Bonan R, Lepage G, et al. Hemodynamic evaluation of the Carpentier-Edwards porcine xenograft. Circulation 1979;60:1170-82.

37 Rothkopf M, Davidson T, Lipscomb K, et al. Hemodynamic evaluation of the Carpentier-Edwards bioprosthesis in the aortic position. Am $\mathcal{F}$ Cardiol 1979;44:209-14.

38 Teoh KH, Fulop JC, Weisel RD, et al. Aortic valve replacement with a smal prosthesis. Circulation 1987;76 (suppl 3):III. 123-31.

(Accepted 14 fuly 1988 )
Department of Internal

Medicine, Central

Hospital, Hillerød,

Denmark

Asger Dirksen, DRMEDSCI, senior registrar

Department of Cardiology, State University Hospital, Copenhagen, Denmark

Erik Kiøller, DRMEDSCI, cardiologist

Correspondence and requests for reprints to: Dr A Dirksen, Noeddehoej 1, DK-2840 Holte, Denmark.

\title{
Cardiac predictors of death after non-cardiac surgery evaluated by intention to treat
}

\author{
Asger Dirksen, Erik Kjøller
}

\section{Abstract}

Cardiac risk factors were studied among patients who were admitted to hospital with appendicitis or a fracture of the proximal femur less than one year after being admitted with myocardial infarction. Of 99 patients with myocardial infarction and appendicitis, 87 underwent appendicectomy; and of 221 with myocardial infarction and hip fracture, 179 were operated on. The patients were studied on an intention to treat basis. The mortality within one month was $9 \%$ and $16 \%$ respectively. A history of congestive heart failure was the dominating risk factor, while ischaemic heart disease (recent myocardial infarction or angina pectoris) had no independent association with mortality.

If the ventricular function is known additional preoperative information about the heart is of negligible value when estimating the mortality of noncardiac surgery.

\section{Introduction}

Congestive heart failure and ischaemic heart disease are considered to be the most important predictors of death after non-cardiac surgery. ${ }^{12}$ Of the ischaemic heart diseases, a recent myocardial infarction is regarded as the most ominous condition, while an older infarction or angina pectoris is less important. ${ }^{3.5} \mathrm{~A}$ recent myocardial infarction is usually defined as one occurring within the preceding six months, and mortality after surgery is typically found to be 10 times higher in patients with recent infarction. ${ }^{4}$ Earlier studies did not take into account the possibility that awareness of risk factors may influence the selection of patients for operation. They were based on a broad range of diseases and many different surgical procedures, including elective operations. They also presented information only about patients who had been operated on-that is, they did not contain any data on patients who for various reasons (for example, recent myocardial infarction) were treated conservatively.

The purpose of the present study was to evaluate cardiac risk factors as predictors of operative death in an adequate number of patients with one specific disease who were all candidates for the same operation, thus minimising the variability associated with differences in disease and operation. We selected two acute conditions (appendicitis and hip fracture) that usually need urgent surgical treatment and analysed data according to the principle of intention to treat. Furthermore, to ensure a high frequency of cardiac risk factors in the study population we confined the study to patients who had suffered myocardial infarction in the year preceding the appendicitis or hip fracture.

\section{Patients and methods}

The national registry of hospitalised patients was established in Denmark in $1976 .^{6}$ The data provided by this registry include diagnoses and operations 
performed while patients are in hospital. The diagnoses are coded according to the World Health Organisation's International Classification of Diseases (eighth revision). From January 1977 to December 1982, 5280539 admissions, 9364985 diagnoses, and 4431935 operations were registered. These figures included 136718 patients who were admitted to hospital with a diagnosis of myocardial infarction.

\section{SELECTION OF PATIENTS}

We began by selecting from the registry the names of all the patients who had been admitted to hospital with myocardial infarction and then were admitted for an operation less than one year later (12544 cases). We constructed a histogram for each surgical diagnosis or operation code showing the numbers of patients admitted with that particular code in each month after the myocardial infarction. Altogether 4027 histograms were constructed, and they showed that appendicitis and fractures of the proximal femur with their corresponding operations (appendicectomy and osteosynthesis of the proximal femur) were the most frequent conditions, giving a total of 921 patients with 2205 admissions to 277 hospital departments.

To establish the validity of the diagnoses and when the acute episodes occurred we needed the discharge records of the patients because the diagnostic coding of the national registry does not distinguish between current and previous disease. We obtained 2158 discharge notes (98\%) for review. There were 101 patients who had had appendicitis and 243 who had fractured a proximal femur less than 12 months after the myocardial infarction.

Two of the 101 patients with appendicitis were omitted from the study because the vagueness of their symptoms had contraindicated surgery. Eighty seven patients were operated on, and the remaining 12 were treated conservatively. Of the 243 patients with hip fractures, 22 received the standard conservative treatment for impacted fracture and were omitted from the study; $179(81 \%)$ were operated on, and the remaining

TABLE I-Sex and age of patients who had suffered myocardial infarction less than one year before appendicitis or hip fracture, showing survival state at one month

\begin{tabular}{|c|c|c|c|c|}
\hline \multirow[b]{2}{*}{ Patient characteristic } & \multicolumn{2}{|c|}{ Appendicitis } & \multicolumn{2}{|c|}{ Hip fracture } \\
\hline & Alive & Dead & Alive & Dead \\
\hline \multicolumn{5}{|l|}{ Sex: } \\
\hline $\begin{array}{l}\text { Female } \\
\text { Male }\end{array}$ & $\begin{array}{l}22 \\
68\end{array}$ & $\begin{array}{l}2 \\
7\end{array}$ & $\begin{array}{r}129 \\
56\end{array}$ & $\begin{array}{l}24 \\
12\end{array}$ \\
\hline Median age at time of event (years) & $63 \cdot 5$ & $70^{\star}$ & 79 & 81 \\
\hline
\end{tabular}

TABLE II-Cardiac risk factors related to mortality within one month after appendicitis or hip fracture in patients who had had at least one myocardial infarction in preceding year

\begin{tabular}{|c|c|c|c|c|}
\hline \multirow[b]{2}{*}{ Risk factor } & \multicolumn{2}{|r|}{ Appendicitis } & \multicolumn{2}{|r|}{ Hip fracture } \\
\hline & $\begin{array}{l}\text { No of } \\
\text { patients }\end{array}$ & $\begin{array}{l}\text { Odds ratio }(95 \% \\
\text { confidence interval) }\end{array}$ & $\begin{array}{l}\text { No of } \\
\text { patients }\end{array}$ & $\begin{array}{l}\text { Odds ratio }(95 \% \\
\text { confidence interval) }\end{array}$ \\
\hline \multicolumn{5}{|l|}{$\begin{array}{l}\text { History (at time of admission for } \\
\text { myocardial infarction): }\end{array}$} \\
\hline Hypertension & 15 & $0.00(0.00-2 \cdot 38)$ & 29 & $0 \cdot 60(0 \cdot 14-2 \cdot 17)$ \\
\hline Diabetes mellitus & 11 & $5.00(0.90-23.60)$ & 23 & $1.63(0.54-5.07)$ \\
\hline Angina pectoris & 41 & $1 \cdot 81(0 \cdot 45-7 \cdot 54)$ & 45 & $0.81(0 \cdot 31-2 \cdot 19)$ \\
\hline Previous myocardial infarction & 27 & $6 \cdot 38^{\star}(1 \cdot 26-31 \cdot 10)$ & 33 & $2 \cdot 51(0.95-6 \cdot 28)$ \\
\hline \multicolumn{5}{|l|}{ Congestive heart failure: } \\
\hline infarction & 9 & $3.31(0.41-18 \cdot 20)$ & 28 & $4 \cdot 05^{\star \star}(1 \cdot 59-10 \cdot 10)$ \\
\hline $\begin{array}{l}\text { During admission for myocardial } \\
\text { infarction }\end{array}$ & 23 & $\alpha^{\star \star \star}(6.69-\propto)$ & 51 & $3 \cdot 10^{\star \star}(1 \cdot 20-8 \cdot 03)$ \\
\hline \multicolumn{5}{|l|}{ Myocardial infarction: } \\
\hline $\begin{array}{l}\text { Definite } \\
\text { Possible }\end{array}$ & $\begin{array}{l}73 \\
26\end{array}$ & $\begin{array}{l}1.27(0.24-9.02) \\
0.79(0.11-4.08)\end{array}$ & $\begin{array}{r}130 \\
91\end{array}$ & $\begin{array}{l}0.98(0.47-2.04) \\
1.02(0.49-2 \cdot 15)\end{array}$ \\
\hline \multicolumn{5}{|l|}{$\begin{array}{l}\text { Time between myocardial infarction } \\
\text { and surgical event }\end{array}$} \\
\hline $\begin{array}{l}\text { 0-3 Months } \\
\text { 4-12 Months }\end{array}$ & $\begin{array}{l}33 \\
66\end{array}$ & $\begin{array}{l}1 \cdot 00(0 \cdot 20-4 \cdot 84) \\
1.00(0 \cdot 21-4 \cdot 91)\end{array}$ & $\begin{array}{l}106 \\
115\end{array}$ & $\begin{array}{l}1.89(0.90-4 \cdot 06) \\
0.53(0 \cdot 25-1 \cdot 11)\end{array}$ \\
\hline
\end{tabular}

${ }^{\star} p<0.05,{ }^{\star \star} p<0.01,{ }^{\star \star \star} p<0.001$, Fisher's exact test.
TABLE III - Numbers of patients with appendicitis or hip fracture according to absence or presence of history of congestive heart failure and time since myocardial infarction. Figures in parentheses are numbers of patients who died within one month after appendicitis or fracture

\begin{tabular}{|c|c|c|c|c|}
\hline \multirow{2}{*}{$\begin{array}{l}\text { Time since } \\
\text { myocardial } \\
\text { infarction } \\
\text { (months) }\end{array}$} & \multicolumn{2}{|c|}{ Appendicitis } & \multicolumn{2}{|c|}{ Hip fracture } \\
\hline & $\begin{array}{l}\text { No history } \\
\text { of congestive } \\
\text { heart failure }\end{array}$ & $\begin{array}{c}\text { History of } \\
\text { congestive } \\
\text { heart failure }\end{array}$ & $\begin{array}{l}\text { No history of } \\
\text { congestive } \\
\text { heart failure }\end{array}$ & $\begin{array}{c}\text { History of } \\
\text { congestive } \\
\text { heart failure }\end{array}$ \\
\hline 0 & 2 & $4(2)$ & $21(3)$ & $12(3)$ \\
\hline 1 & 7 & $2(1)$ & $20(4)$ & $10(3)$ \\
\hline 2 & 6 & 2 & $10(2)$ & $11(3)$ \\
\hline 3 & 9 & 1 & $14(1)$ & $8(3)$ \\
\hline 4 & 9 & 2 & $12(2)$ & $9(2)$ \\
\hline 5 & 5 & $1(1)$ & 10 (1) & $7(1)$ \\
\hline 6 & 7 & l(1) & $11(1)$ & $2(1)$ \\
\hline 7 & 4 & $2(1)$ & 12 & 3 \\
\hline 8 & 2 & 4 & $10(2)$ & \\
\hline 9 & 5 & & $6(1)$ & 1 \\
\hline 10 & 5 & $3(1)$ & $12(1)$ & \\
\hline 11 & 4 & $3(1)$ & 5 & $5(1)$ \\
\hline 12 & 6 & 3 (1) & $6(1)$ & 1 \\
\hline
\end{tabular}

42 received conservative treatment for non-impacted fracture. For six patients with appendicitis and 33 with hip fracture we could not establish whether the myocardial infarction or the appendicitis or fracture had occurred first. In these cases the interval between the two was set to 0 months.

\section{RISK FACTORS}

Information on the presence or absence of hypertension, diabetes mellitus, ischaemic heart disease, and congestive heart failure was obtained from the patients' discharge notes for the admission with myocardial infarction (without knowledge of the subsequent admission and its outcome). Congestive heart failure was defined as the presence of one or more of the following symptoms: severe dyspnoea at rest, orthopnoea, enlargement of the liver, or peripheral oedema. Congestive heart failure that occurred before the admission for myocardial infarction was distinguished from that which first occurred during the admission. Myocardial infarction was classified as definite or possible by one of us (EK).

\section{DATA ANALYSES}

Data were analysed on an intention to treat basisthat is, surgically and conservatively treated patients were analysed together. The median time between onset of symptoms and surgery was one day for appendicitis and two days for hip fractures. The relation between the risk factors and the mortality one month after the appendicitis or fracture was analysed in contingency tables by Fisher's exact test.

\section{Results}

Table I shows the age and sex distributions of the patients studied. Of the 99 patients with appendicitis, nine died in the month after its onset, giving a mortality of $9 \%$ (figure). Table II shows that congestive heart failure was the most significant risk factor in the patients with appendicitis $(p<0.001)$. Two of those who died had had congestive heart failure before being admitted with myocardial infarction and the seven others had it as a complication of their myocardial infarction. Of the 90 patients who survived appendicitis, only 19 had a history of congestive heart failure. Multiple infarction - that is, an infarction before the index one-was also a significant risk factor $(p<0.05)$. The six patients with multiple infarction who died, however, all also had a history of congestive heart failure.

Table III shows that the cases of appendicitis were evenly distributed over the year after the myocardial infarction. Recent infarction did not increase the 
mortality, which was $9 \%$ both in the period up to three months after myocardial infarction and in the period from four to 12 months after infarction; the difference in mortality between the two periods was therefore zero $(95 \%$ confidence interval $-12 \%$ to $12 \%)$.

Of the 221 patients who fractured their hips, 36 died within one month, giving a mortality of $16 \%$ (figure).

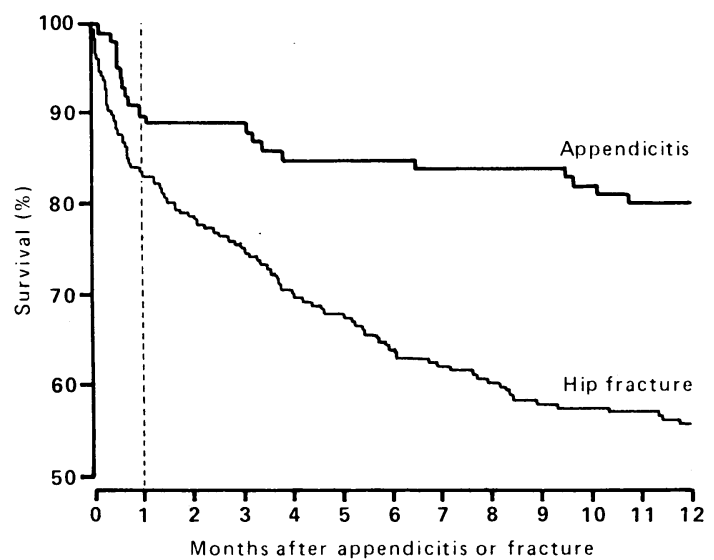

Survival of 99 patients with appendicitis and 221 patients with fracture of proximal femur who had had myocardial infarction less than a year before

Congestive heart failure was the only risk factor that was significant in these patients $(p<0 \cdot 05)$. Of 70 patients with a history of congestive heart failure (either before the myocardial infarction or as a complication of it), 17 (24\%) died in the month after fracturing their hip; while of 151 patients who did not have a history of congestive heart failure, only $19(13 \%)$ died. A recent myocardial infarction (within three months before the fracture) was associated with a mortality of $21 \%$ and an older myocardial infarction (four to 12 months before the fracture) with a $12 \%$ mortality. The difference in mortality between the two periods ( $9 \%$ (confidence interval $-1 \%$ to $18 \%$ )) was not significant.

Table III shows that cases of hip fracture were not evenly distributed in the year after the myocardial infarction. There was an accumulation of patients with a history of congestive heart failure in the first months after the infarction, and when the high mortality of this condition was taken into account the observed difference in mortality between recent and older myocardial infarction diminished.

\section{Discussion}

A nationwide computerised patient registry makes it possible to trace adequate numbers of patients with similar conditions. The present study differed from previous studies of cardiac risk factors by confining analyses to two specific conditions requiring operation, thereby minimising the variability between groups of patients caused by differences in disease and operation. Other studies have shown that there is a greatly increased risk in the first months after a myocardial infarction, but this is probably due to sampling biasthat is, surgery in the early period after infarction cannot be assumed to be comparable with surgery later. The other studies included very few patients with a recent myocardial infarction. The study by Goldman et al of 1001 patients included only 22 patients who were operated on in the first six months after a myocardial infarction, ${ }^{3}$ and although a study at the Mayo Clinic of 73321 patients who were operated on contained 587 who had had myocardial infarction, only 15 of these had had the infarction within three months.

We believe that doctors tend to postpone operations whenever possible and avoid causing stress in the first critical months after a myocardial infarction. This imposes a selection bias because only the more urgent cases are operated on, and urgent surgery in itself carries increased risk. We believe that the correct approach for evaluating operative risk is to apply the intention to treat principle, as is used to assess drug treatments. Patients treated conservatively can constitute an important bias, which is concealed if only the results of operations are presented.

Previous studies have evaluated operative risk relative to more specific end points such as fatal or nonfatal recurrent infarction and cardiac complications. ${ }^{3.5}$ Because of the retrospective nature of our study and because death was often related to multiple factors we abandoned an attempt to catalogue the cause of death. The figure shows that deaths were quite evenly spread over the first month, after which the survival curves became flatter - that is, deaths were not a direct result of the operation itself but occurred in the period when the endocrinological and metabolic consequences of the operation strained the heart.

In agreement with other studies we identified congestive heart failure as the most important cardiac risk factor in relation to surgery. ${ }^{34}$ We were not able, however, to show that a recent myocardial infarction is an independent predictor of mortality in non-cardiac surgery. The results for patients with appendicitis imply that it is the degree of myocardial damage and ventricular impairment produced by one or more myocardial infarctions that is important rather than just the history of infarction.

If a recent infarct is discounted as a serious risk factor and the possible cardiac risk factors at operation are assessed congestive heart failure emerges as the predominant factor and other factors such as previous myocardial infarction, stable or unstable angina pectoris, and arrhythmia seem to play only a minor part. ${ }^{34}$ This qualitative finding agrees with findings of previous studies. Future studies should assess ventricular function before surgery, thereby permitting a quantitative assessment of the relation between ventricular function and operative risk. When such information becomes available the other cardiac risk factors should be re-evaluated.

This work was supported by grants from the Danish Heart Foundation and the Medical Research Foundation of hospitals in region 3 .

1 Logue RB. Evaluation and management of patients with heart disease who undergo non-cardiac surgery. In: Hurst JW, ed. The heart. 6th ed. New York: McGraw-Hill, 1986:1511-9.

2 Wolf MA, Braunwald E. General anesthesia and non-cardiac surgery in patients with heart disease. In: Braunwald E, ed. Heart disease. 2nd ed. Philadelphia: W B Saunders, 1984:1815-25.

3 Goldman L, Caldera DL, Nussbaum SR, et al. Multifactorial index of cardiac risk in non-cardiac surgical procedures. $N$ Engl f Med 1977;297:845-50.

Larsen $\mathrm{SF}$, Olesen $\mathrm{KH}$, Jacobsen $\mathrm{E}$, et al. Prediction of cardiac risk in noncardiac surgery. Eur Heart $f$ 1987;8:179-85.

5 Steen PA, Tinker JH, Tarhan S. Myocardial reinfarction after anesthesia and surgery. JAMA 1978;239:2566-70.

6 Jürgensen HJ, Frølund C, Gustafsen J, Mosbech H, Guldhammer B, Mosbech J. Registration of diagnoses in the Danish national registry of patients. Methods Inf Med 1986;25:158-64.

(Accepted 4 fuly 1988)

\section{Correction}

Intraperitoneal calcium for resistant symptomatic hypocalcaemia after parathyroidectomy in chronic renal failure

We regret that an editorial error occurred in this article by $\operatorname{Dr} \mathrm{T} \mathrm{J}$ Thompson and T J Neale (26 March, p 896), which was not spotted by the authors before it was published. In the figure the units for the intravenous calcium infusion should have read $\mathrm{mmol} / \mathrm{h}$ and those for intraperitoneal calcium $\mathrm{mmol} / \mathrm{day}$. In addition the decimal points for serum calcium $(\mathrm{mmol} / \mathrm{l})$ on the vertical axis and for 1,25 dihydroxyvitamin D3 ( $\mu \mathrm{g} /$ day) were inadvertently omitted from the figure. 